\title{
IDENTIDADES E FRONTEIRAS ÉTNICAS NO PROCESSO DE INSERÇÃO DOS IMIGRANTES HAITIANOS NO MUNICÍPIO DE CASCAVEL/PR
}

\author{
IDENTITIES AND ETHNIC FRONTIERS IN THE INSERTION \\ PROCESS OF HAITIAN IMMIGRANTS IN THE MUNICIPALITY OF \\ CASCAVEL/PR
}

Eric Gustavo Cardin ${ }^{1}$

Carmem Aparecida Manica ${ }^{2}$

\begin{abstract}
RESUMO: O objetivo do artigo é analisar o processo de inserçáo social dos migrantes haitianos no município de Cascavel/Paraná, explorando os obstáculos enfrentados pelos migrantes e as redes sociais constituídas. Năo suficiente, partindo do pressuposto que as identidades sâo relacionais, refletimos sobre as relaçôes entre redes sociais, inserçăo social e as fronteiras étnicas. Para tanto, o estudo utilizou de entrevistas qualitativas realizadas entre 2015 e 2017 e possibilitou o entendimento de que as estratégias de construção identitárias nâo săo ideais puros, mas coexistem nas práticas cotidianas dos migrantes.
\end{abstract}

PALAVRAS-CHAVE: Migraçăo haitiana. Identidade. Fronteiras étnicas.

ABSTRACT: The objective of this article is to analyze the process of social insertion of Haitian migrants in the municipality of Cascavel / Paraná, exploring obstacles faced by migrants and social networks. Not enough, based on the assumption that identities are relational, we reflect on the relationships between social networks, social insertion and ethnic boundaries. For that, the study used qualitative interviews conducted between 2015 and 2017 and allowed the understanding that identity construction strategies are not pure ideals but coexist in daily practices of migrants.

KEYWORDS: Haitian migration. Identity. Ethnic boundaries.

1 Doutor em Sociologia pela Universidade Estadual Paulista (UNESP). Pós-doutor em Antropologia Social pela Universidad Nacional de Misiones (UNAM/Argentina). Professor do Programa de Pós-graduaçâo em Sociedade, Cultura e Fronteiras. Coordenador do Grupo de Pesquisa Fronteiras, Estado e Relaçóes Sociais (LAFRONT). eric_cardin@hotmail.com

2 Mestre em Ciências Sociais pela Universidade Estadual do Oeste do Paraná (UNIOESTE). Graduada em História (UNIPAR). Professora da Secretaria do Estado do Paraná. carmem.manica@gmail.com 


\section{INTRODUÇÃO}

Nas últimas duas décadas o Brasil se tornou um país receptor de inúmeros migrantes latino-americanos, com destaque para os bolivianos, paraguaios, venezuelanos e haitianos. Consequentemente, ocorreram diferentes fatos sociais derivados das interaçôes características das fronteiras étnicas em vários pontos do território nacional durante o mesmo período. Partindo desta observaçáo inicial, explicita-se que o objetivo do presente artigo é analisar a relaçâo entre o processo de inserçâo social dos haitianos e a constituiçăo de redes sociais no município de Cascavel, estado do Paraná, Brasil. Neste intuito, serăo analisados o acolhimento dos migrantes e a importância da educaçấo e da religiâo no intuito de se respaldar uma reflexăo sobre as fronteiras étnicas impostas.

O migrante ao chegar ao local de destino se depara com novas configuraçôes religiosas, culturais, econômicas e sociais, configuraçôes que interagem com as experiências e os valores acumulados durante sua trajetória de vida. Com a migraçăo e o contato com uma nova realidade, vários aspectos da vida do migrante acabam sendo impactados, resultado direto do contato com o "novo". Para Bhabha (1998), durante esse encontro entre o novo e o antigo, entre o nativo e o estrangeiro, o migrante reencena, negocia e redefine sua cultura. Nesse aspecto, Dantas (2010) pondera que o migrante traz consigo uma carga simbólica, mas no encontro com o outro acaba por ter um conflito interno contínuo, que coloca em xeque o seu próprio modo de ser.

Segundo Marandola (2008), migrar é sair do seu lugar, o que resulta em um processo de redefiniçóes e em uma açâo de aventurar-se em lugares de pouca ou nenhuma familiaridade, onde há pouco ou nenhum controle. Nesse sentido, Rosana Baeninger e Sylvain Souchaud (2007, p. 04) argumentam que:

Hoje a migraçăo, em muitos casos, năo é um processo linear, mas feita de desvios, retornos, idas e vinda. A multiplicaçâo dos lugares na migraçăo năo é aleatória, constitui ou acaba formando uma estratégia na qual os espaços săo considerados como recursos num recurso cumulativo. A circulaçăo de indivíduos e de bens de informaçôes que lhes sâo associados, em diferentes espaços articulados entre si, criam uma dinâmica territorial complexa.

Arjun Appadurai (2004) afirma que os fluxos migratórios e o deslocamento de refugiados podem transformar as vidas cotidianas em novos projetos sociais. Logo, torna-se relevante observar que esses grupos ou comunidades de migrantes cada vez mais desejam ampliar seu pertencimento político e buscar, por meio da cidadania, o seu reconhecimento (SASSEN, 2014). Diante disso, o presente artigo explora estas dimensôes ao analisar o processo de inserçâo social dos migrantes haitianos e as fronteiras étnicas estabelecidas, com maior atençâo aquelas existentes no município de Cascavel. Em grande medida, a chegada dos haitianos e a falta de estrutura do país para recebê-los fizeram com que a sociedade civil desenvolvesse diferentes açóes de 
acolhimento.

No intuito de contribuir com o entendimento do fenômeno migratório, mais precisamente para as abordagens centradas nas configuraçôes das redes sociais e das identidades no interior das relaçôes estabelecidas nas fronteiras étnicas, serăo utilizadas algumas entrevistas realizadas com agentes pertencentes à sociedade civil organizada e também com um conjunto de migrantes. Com o uso de um roteiro semiestruturado, foram entrevistados dois representantes de instituiçóes que atuam no acolhimento dos haitianos no intuito de problematizar as relaçôes de poder que envolvem esta atividade, e também com dez migrantes haitianos (oito homens e duas mulheres), buscando explorar as leituras que os próprios migrantes fazem do processo de inserçáo e das redes sociais constituídas (é importante ressaltar que nem todas as entrevistas estâo expostas diretamente neste texto).

$\mathrm{O}$ artigo está organizado em três partes. Primeiramente, será abordado o processo de acolhimento destes sujeitos, que em grande medida ocorre por meio de redes privadas, confessionais ou laicas. Em um segundo momento, será analisado o acesso à educaçâo e as dificuldades impostas pelo idioma. Por fim, serâo apresentados alguns aspectos relacionados à importância da religiăo no processo de inserçăo ao mesmo tempo em que se expressam manifestaçóes xenofóbicas. Devido ao recorte estabelecido no presente estudo, questôes mais diretamente vinculadas à inserçáo laboral náo serâo contempladas.

\section{A ESTRUTURA DE ACOLHIMENTO DOS HAITIANOS}

A chegada dos migrantes no país de destino corresponde a um problema que envolve inúmeras dimensôes. Nesse sentido, questóes relacionadas ao impacto econômico e social dos fluxos migratórios e também reflexóes sobre a pré-existência de redes sociais de recepçăo e de estrutura de acolhimento săo temas que tangenciam este momento. Semelhante a outras localidades do território brasileiro, o município de Cascavel năo possui abrigos estatais para o acolhimento dos migrantes haitianos, em grande medida, cabe às instituiçôes religiosas o desenvolvimento desse papel.

Rosangela Silva Ferreira, pedagoga e membro da Cáritas Arquidiocesana de Cascavel, destaca que a falta de uma estrutura pública de recebimento desta populaçáo exige respostas da sociedade civil organizada. Corroborando neste aspecto, o reverendo da Igreja Anglicana, Luiz Carlos Gabas (2014), afirma que:

A igreja náo pode se furtar de uma de suas principais funçôes que é compromisso com os direitos humanos. Temos essa preocupaçấo da proteçăo e do acolhimento dessas pessoas que vêm de outros países que vêm à Cascavel em busca de um recomeço (LAÍNY, 2014, p. 1).

Em conformidade com a questâo do acolhimento é possível perceber a existência de algumas açôes nos estados do Amazonas, Sâo Paulo e Santa Catarina. No tocante ao município de Manaus cabe destacar a pesquisa de Kátia Couto (2016), que descreve a acolhida dos migrantes haitianos pela Pastoral do Migrante. A referida autora destaca que os migrantes foram abrigados em vários alojamentos localizados em seis bairros da cidade, como também na própria Casa de Acolhida da Pastoral do Migrante. 
A Pastoral do Migrante (SPM) da Arquidiocese de Manaus, atuou de foram efetiva no acolhimento de migrantes haitianos, através de várias atividades e medidas que buscavam garantir serviços de assistência imediata e articulando parcerias no intuito de inserir esses migrantes no ambiente social de destino (COUTO, 2016, p. 170).

Segundo Andréia B. de Souza e Leila de Menezes Stein (2015), uma grande quantidade de migrantes haitianos é acolhida pela Missăo de Paz no município de Săo Paulo, capital do estado brasileiro que mais recebe imigrantes haitianos.

Até o final de 2015, Săo Paulo já havia recebido cerca de 60\% do fluxo migratório haitiano, e foi considerado o estado que mais acolheu os haitianos que chegavam pelo Acre e pelo Amazonas. Destes imigrantes, grande parte foi e ainda está sendo amparada na Paróquia Nossa Senhora da Paz(Missăo Paz), instituiçăo religiosa ligada à Igreja Católica que conta com uma equipe diversa e especializada no acolhimento de migrantes e refugiados, ajudando-os com alimentaçăo, documentaçăo, moradia e emprego (SOUZA; STEIN, 2017, p. 5).

Conforme Paolo Parise (2016), a Missâo da Paz começou sua atuaçâo na década de 1930 no município de Sáo Paulo e atualmente tem sua estrutura formada pela Casa do Migrante, que tem a capacidade de atender 110 migrantes ou refugiados. Além disso, a missâo possui o Centro Pastoral e de Mediaçâo dos Migrantes, que auxilia nos aspectos de documentaçâo, jurídicos, laborais, de saúde e educaçăo, atendendo os núcleos familiares e a comunidade. Faz parte também da estrutura da Missăo da Paz o Centro de Estudos Migratórios e a Igreja Nossa Senhora da Paz.

Também merece destaque a pesquisa de Gláucia de Oliveira Assis e Luís F. A. Magalhăes (2016), que revelou que após o recrutamento de migrantes haitianos por empresas do estado de Santa Catarina a vinda destes passou a ser mediada pelas redes sociais.

\begin{abstract}
Estas redes sociais possuem como principal expressáo atualmente a existência de Associaçōes de Haitianos nestas cidades, especialmente em Balneário Camboriú, Itajaí e Navegantes. Passam pelas associaçôes os trâmites trabalhistas, a ajuda com a hospedagem e o encaminhamento das questôes relacionadas à educaçáo e à saúde dos imigrantes. Cada um destes fatores relaciona-se com a abertura da possibilidade de se trazer parentes e amigos que ainda permaneceram no Haiti. Até junho de 2014, havia em Balneário Camboriú dois estabelecimentos com o intuito de facilitar a integraçăo na cidade e oferecer serviço de telefonia e comunicaçăo por internet com seus amigos e familiares (ASSIS; MAGALHÂES, 2016, p. 237).
\end{abstract}

Em certa medida, a atuaçăo dessas entidades exerce funçôes que deveriam ser de responsabilidade do Estado. Dessa forma, atuam fortemente nas lacunas deixadas pela açâo estatal, configurando como espaços nos quais os indivíduos que compôem os fluxos migratórios buscam a primeira acolhida em território brasileiro (ARAÚJO, 2016). Para Redin (2013), o Estado mantém o migrante sob um espectro de pseudodireitos, desprezando as demandas necessárias para a manutençâo de uma vida digna no país, ou seja, eles săo inicialmente incluídos para entăo serem excluídos pelo país de destino. Corroborando com esse entendimento, Araújo (2016, p. 392) afirma que:

Sem dúvida, quando analisamos as estruturas administrativas do Estado brasileiro voltadas para a realidade migratória vemos que no nível federal as funçōes se dividem entre o Ministério da Justiça e do Trabalho, algo aparentemente óbvio, pois 
săo os órgăos que tratam de duas dimensōes importantes do fenômeno - a dimensăo jurídica e da permanência de estrangeiros em território nacional; e a principal atividade, o trabalho, que os indivíduos buscam como forma para se inserirem na sociedade de destino. Tanto que a dimensăo do trabalho sempre está presente nos discursos dos atores envolvidos com os fenômenos migratórios e parece ser uma das principais dimensôes presentes nos discursos dos agentes de Estado quando se tratam de estabelecer açóes para a populaçăo migrante, bem como para seus indivíduos.

Nesse sentido, cabe ressaltar a ausência do Estado nas questóes jurídicas de regularizaçăo dos migrantes haitianos que chegaram ao Brasil em 2010. O movimento inicial foi a tentativa de obtençâo do status de refugiado, mas devido ao năo enquadramento na categoria descrita pela convençăo de 1951, a soluçăo encontrada pelo CNIg foi conceder o visto por razóes humanitárias. Apesar do avanço nesse âmbito, com a Nova Lei de Migraçóes (n 13.445/2017), Moraes (2017, p. 44-45) afirma que "o Estado mantém estruturas determinantes no destino dos migrantes".

\begin{abstract}
Destarte, embora os ressaltados avanços trazidos com o advento da Nova Lei de Migraçăo no tocante à questăo dos direitos humanos do imigrante, manteve-se espaço para a seletividade do Estado no que concerne à entrada de imigrantes no País, à medida que abre brechas para estabelecer óbices quase instransponíveis aos imigrantes considerados indesejáveis, potencializando a proteçáo do Estado em detrimento da proteçăo ao sujeito (MORAES, 2017, p.45).
\end{abstract}

Observa-se que após o migrante ter o primeiro contato com as estruturas administrativas do país, por meio da Polícia Federal, para sua regularizaçăo, ele năo encontra nenhuma estrutura de inserçăo. Geralmente as açôes empreendidas pelo Estado brasileiro em relaçáo à migraçâo sâo açôes pontuais e paliativas, nâo tratam das estruturas nos âmbitos social, político e econômico. Corroborando esta ideia, Arruda (2015 p. 23) afirma que:

Pensar a participaçăo do Estado na formulaçăo de uma política migratória com iniciativas no sentido da inserçăo social de estrangeiros implica em definir açóes e metas que procurem lidar com essas questooes evitando essa tendência à exclusăo e marginalizaçăo de imigrantes.

A ausência do Estado nas questôes relacionadas ao fluxo migratório haitiano leva as entidades de cunho religioso, juntamente com as ONG's (Organizaçôes Nâo Governamentais), a uma centralidade na inserçâo e acolhimento destes imigrantes. Nesse sentido, Araújo (2016, p. 393), assevera que:

Estas entidades realizam importantes açôes no sentido de providenciarem abrigo provisório e inicial em território brasileiro, alimentaçăo, além de intervençōes diretas no sentido de colocarem os migrantes com o mercado de trabalho brasileiro.

É importante destacar que as instituiçōes religiosas vâo além do acolhimento, implementando açôes que visam a inserçăo dos imigrantes haitianos em várias esferas. Nesse sentido, vale salientar que, durante o caminho percorrido na pesquisa, o campo constituiu-se em uma relaçăo contínua, năo sendo reduzido apenas a entrevistas, pois envolveu observaçáo participante, principalmente no Fórum dos Haitianos, que possibilitou a compreensâo de algumas das formas de organizaçáo que os haitianos estabeleceram em Cascavel. O fórum foi criado em 2016 com o intuito de desenvolver 
estratégias para a inserçăo dos imigrantes haitianos. Nas reunióes participam, além dos haitianos, membros da Cáritas, pesquisadores vinculados a universidades, bem como representantes do poder público. Integrante do Fórum, Rosangela Silva Ferreira (2017) explica seu funcionamento e objetivos:

Nós apoiamos que os haitianos se organizem, incentivamos o que a gente chamou
de Fórum só de haitianos, eles se reúnem aqui na Cáritas uma vez por mês. Nós
trabalhamos com a metodologia do coletivo, ou seja, existe um Plano Estadual de
Políticas Públicas para a promoçáo da defesa dos direitos dos refugiados, migrantes
e apátridas do Paraná, que vai discutir eixos de educaçáo, trabalho e saúde. E na
questáo dos direitos nós vamos orientá-los para que eles possam lá na comunidade
deles, através do Fórum, estar trazendo as maiores necessidades que eles possuem.
A partir disso vamos passar a provocar o município e o estado. Por exemplo, nós
participamos 10 dias atrás, do Conselho Estadual do Trabalho e Economia, em nível
de Estado, que aconteceu na ACIC, pra dizer que nós estamos com dificuldades de
trabalhar nesse sentido. Nós provocamos também o município, dizendo que náo
dá mais para colocar debaixo do tapete, está aí e alguma coisa vai ter que ser feita,
entâo acho que é esse o papel, o de provocar, dialogar, dizer que a gente tem de se
unir.

Além do Fórum dos Haitianos, a Cáritas, em parceria com a Pastoral dos Migrantes, organizou o $1^{\circ}$ Festival da Cultura Haitiana, que ocorreu no salâo da Igreja Sâo Cristóvâo em 28 de maio de 2016. O festival contou com apresentaçôes e a venda de artesanato e comidas típicas. Uma das iguarias vendidas no evento foi a lasanha de banana, que apesar de nâo ser uma comida típica do Haiti, tem como principal ingrediente a banana, que é uma fruta muito utilizada na culinária haitiana, como, por exemplo, na preparaçăo do fritay, que corresponde a uma espécie de banana frita temperada com condimentos.

Em conformidade com a questâo de açôes que visam à manutençăo de práticas culturais haitianas e a inserçâo dos migrantes no município de Cascavel, a Cáritas oferece cursos de artesanato às mulheres haitianas. Nesse sentido, Ferreira (2017) esclarece como funcionam tais cursos.

Nós estamos oferecendo aulas de artesanato pra mulheres haitianas, entâo o artesanato acaba por fortalecer a cultura delas com o Haiti e além do curso a gente também organiza as feiras de economia solidária, bem como as festas de igreja para elas colocarem os produtos à venda.

Os produtos confeccionados pelas haitianas expressam um pouco da cultura do país natal. Os itens văo desde panos de prato e descansos de panelas a agendas, cadernos, blocos de anotaçôes e até bolsas. Os produtos confeccionados nos cursos de artesanato proporcionados pela Cáritas além de serem vendidos nas festas da igreja e em feiras, também săo vendidos nos bazares de economia solidária, que ocorrem na própria instituiçăo, um sábado por mês, no período vespertino.

Essas açôes organizadas pelas instituiçôes religiosas e pelas ONG's, que vâo desde o acolhimento até a inserçăo dos imigrantes haitianos, acabam por minimizar e auxiliar no enfrentamento dos problemas encontrados no fluxo migratório. Contudo, existem iniciativas dos próprios imigrantes. Nesse sentido, cabe mencionar a criaçăo da Associaçấo de Defesa da Populaçáo Haitiana no ano de 2014. A primeira assembleia da associaçấo foi realizada em 13 de abril daquele ano e contou com a presença de 
aproximadamente 80 haitianos. No dia 04 de maio de 2014 os haitianos voltaram a se reunir para definir os membros responsáveis pela coordenaçăo da associaçăo e para discutir a realizaçăo de um evento para a comemoraçăo do Dia da Bandeira Haitiana.

A reuniăo aconteceu na Câmara de Vereadores e contou com a presença de cerca de 30 haitianos. Neste início de organizaçáo, a associaçáo contará com uma direçâo provisória com prazo de um ano. Dividida por coordenaçóes, a entidade irá elencar demandas dos haitianos na cidade, em especial nas áreas trabalhistas, de documentaçăo, saúde e educaçăo. A associaçâo será coordenada por Joe Evens Celintery (coordenador geral) e Marcelin Geffard (coordenador auxiliar). A entidade ainda contará com um secretário geral, um responsável pelas finanças, comunicaçăo, além de delegados e conselheiros, sendo um deles brasileiro: o professor Elemar Muller (CARIGNANO, 2014, p.01).

Além das açôes mencionadas, foram confeccionados exemplares de uma cartilha em português e créole haitiano com informaçôes a respeito do processo migratório. Em 2016 a Associaçáo Haitiana de Cascavel realizou o Show des Arts, que contou com apresentaçôes artísticas e culturais haitianas, na ocasiâo o valor da entrada foi integralmente destinado à associaçăo (EBERHARDT, 2017). Por fim, outra açâo que merece ser destacada, foi a criaçăo de um programa de rádio, em 2014, voltado nâo só aos imigrantes haitianos que residem em Cascavel e regiâo, mas também aos familiares destes que têm acesso ao programa via internet.

Além de matar a saudade da cultura e da família que deixaram no país de origem, o programa Haiti Universal também é uma ferramenta para auxiliar aqueles que vivem refugiados na regiăo. Eles, bem como outros haitianos espalhados pelo Brasil, nem sempre conseguem falar com frequência com os familiares e por vezes têm dificuldades em encontrar boas oportunidades por aqui, diferentemente do que imaginavam quando migraram para cá. Uma programaçấo voltada para eles é como ter um pedacinho do Haiti aqui. Em funçăo disso, até mesmo a escolha das músicas é feita com cuidado para que os haitianos se sintam reconfortados com as mensagens que vâo ao ar (CRISTINA; BIANCO, 2014, p.01).

Outro aspecto importante que merece atençăo refere-se às moradias ocupadas pelos haitianos nas cidades brasileiras. A pesquisa de campo do pesquisador Geraldo C. Cotinguiba (2014), realizada em Porto Velho, Rondônia, revelou que alguns proprietários se negam a alugar seus imóveis aos haitianos, chegando a aumentar os valores dos mesmos.

A referida área da cidade onde vivem os haitianos - localizada em alguns bairros próximos à área central da cidade - é marcada pelo que se conhece localmente como "estâncias", ou seja, vários quartos num mesmo imóvel - chamados apartamentos ou quitinetes em um mesmo terreno, locados a preços que variam entre $\mathrm{R} \$ 300,00$ a R\$ 500,00, além da conta de luz e uma contribuiçăo para a conta d'água. Sáo divididos por dois, três e até mesmo por cinco pessoas. Sáo verdadeiros cortiços, muito mal construídos, sem ou com pouquíssima ventilaçăo, às vezes com banheiro coletivo, cobertos com telhas de amianto (COTINGUIBA, 2014, p.139).

No município de Cascavel, a situaçăo das moradias ocupadas pelos haitianos nâo diverge muito da de outras cidades brasileiras. Nesse sentido, Ferreira (2017) afirma que:

Moram cinco, seis, sete pessoas em casas muito pequenas ou quitinetes, outro fator é o fato de que o proprietário do imóvel se sente prejudicado, pois aluga o imóvel pra 
três pessoas, de repente há cinco, seis, sete pessoas, sendo que um ou dois trabalham, no máximo.

Em relaçăo às áreas em que os migrantes residem no município de Cascavel, observa-se a predominancia das regiōes Sul, Leste e Oeste. Segundo Eberhardt (2017, p. 86), as moradias alugadas pelos haitianos estăo localizadas, "sobretudo, nos bairros Universitário e Santa Felicidade (Sul); Sáo Cristovăo, Cascavel Velho, Cataratas e Morumbi (Leste); Santa Cruz e Santo Onofre (Oeste)". Em conformidade com essa questăo, em 2017, uma matéria divulgada pela CATVE (2017), informou que no Alto Alegre residiam 565 haitianos, enquanto 413 moravam no Coqueiral, ambos bairros da regiâo oeste do município.

Na parte sul da cidade está localizada a UNIOESTE, campus Cascavel, dessa forma a regiăo conta com várias opçôes de imóveis para locaçăo. Nas proximidades da universidade também está localizada a Cooperativa Agroindustrial de Cascavel (Coopavel), uma das maiores empregadoras de imigrantes haitianos do município. A regiăo leste, por sua vez, possui acessos à BR-469 e a BR-277, que dá acesso à Coopavel. Já na regiâo oeste está localizada a Prefeitura Municipal de Cascavel, o Terminal Rodoviário, uma universidade privada e dois centros universitários. Dessa forma, a regiăo também conta com vários imóveis para a locaçáo. Um dos centros universitários instalado na regiăo é o Centro Universitário Fundaçăo Assis Gurgacz (FAG), que conta com trabalhadores haitianos em seu quadro de funcionários. Nota-se que, as áreas de residência dos haitianos săo, em sua maioria, bairros próximos das empresas em que eles trabalham ou das estruturas que frenquentam e utilizam, bem como bairros que possuem opçóes de imóveis baratos para a locaçăo, principalmente quitinetes.

Por meio das redes constituídas no município de Cascavel os imigrantes haitianos desenvolveram açōes de inserçâo na regiāo. Açôes como o Fórum dos Haitianos, a Associaçăo dos Haitianos, o $1^{\circ}$ Festival da Cultura Haitiana e o Show des Arts. Dessa forma, constata-se que o fluxo migratório haitiano năo se encerra de maneira simples, pois ele está vinculado diretamente à conquista de um espaço que lhes garanta melhores condiçôes de vida em um sentido amplo, algo que nâo se restringe ao mercado de trabalho. Contudo, é interessante pensar que no âmbito da migraçăo o Estado configura um agente com açôes dúbias. De um lado, ele possui a preocupaçăo de elaborar um estatuto para o estrangeiro e um protocolo de atendimento ao imigrante e ao refugiado, por outro lado, náo possui a mesma dedicaçáo em garantir o cumprimento das suas próprias deliberaçóes. Esta situaçâo abre espaço para que outros agentes da sociedade civil se mobilizem e garantam sua própria existência por meio de diferentes açôes.

\section{EDUCAÇÃO E GÊNERO NO PROCESSO DE INSERÇÃO SOCIAL}

A estrutura de acolhimento é um elemento fundamental no processo de inserçáo social dos imigrantes no país, porém ela năo é o único aspecto a ser observado. Em grande medida, existem outras dimensóes sociais que interferem diretamente no êxito ou năo do processo de inserçăo dos imigrantes. Nesse sentido, a presente seçâo abordará dois pontos que merecem destaque: a educaçâo e as relaçôes de gênero. Abrangerá ainda as açóes empreendidas pelo governo brasileiro, bem como pela sociedade civil, que objetivam garantir o acesso à educaçăo e o aprendizado da língua pelos imigrantes. 
No entender de Gorczevski (2005), o elemento fundamental para a cidadania é a educaçăo. Para o autor a base da cidadania é o desenvolvimento integral do homem, o respeito aos direitos humanos e às liberdades fundamentais, a compreensăo, a tolerância e a amizade entre os grupos étnicos e religiosos e entre as naçōes. Nesse sentido, Santos (2001, p. 65) afirma que:

Para que o cidadăo possa atuar no sindicato, no partido político etc., é necessário que ele tenha acesso à formaçăo educacional, ao mundo das letras e domínio do saber sistematizado. Em consequência disso a formaçăo do cidadăo passa necessariamente pela educaçăo escolar.

No contexto do fluxo migratório haitiano, o debate sobre a inserçăo social perpassa os direitos assegurados, incluindo-se aí o direito à educaçăo. Alice Krämer Iorra Schmidt e Márcia Solange Volkmer (2016), analisando uma escola municipal na cidade de Arroio do Meio, no Rio Grande do Sul, onde existiam seis alunos haitianos de idades entre 6 e 17 anos, verificaram a inexistência de políticas públicas estaduais ou municipais para a inserçâo dos imigrantes na escola. As iniciativas observadas partiram diretamente do próprio corpo docente da escola. Conforme Schmidt e Volkmer (2016, p.12):

\begin{abstract}
Algumas adaptaçóes na sistemática de aula foram realizadas para permitir um melhor acolhimento dos imigrantes pela escola e superar algumas dificuldades com relaçáo à comunicaçăo. Num primeiro momento, a instituiçăo buscou auxílio de uma pessoa, na comunidade, que falasse francês para permitir esse contato inicial com os pais dos alunos estrangeiros, compreender quem eram esses recém-chegados, onde estavam trabalhando no Brasil, no que trabalhavam no Haiti e traduzir eventuais documentaçóes. Na sala de aula, a comunicaçâo foi estabelecida através do uso de computador ou aparelho celular para acessar programas de traduçăo, a exemplo do Google Tradutor, a fim de permitir a melhor compreensăo, por alunos e professores, do francês e do créole, que săo as línguas oficiais do Haiti.
\end{abstract}

Embora no município de Cascavel a situaçăo dos alunos haitianos matriculados na rede municipal năo seja muito diferente daquela apresentada em Arroio do Meio, foram constatadas, ao longo da pesquisa, algumas experiências estatais que visam facilitar a inserçâo dos migrantes via educaçâo pública. Conforme reportagem de Aline Cristina e Bruna B. da Luz, publicada em 2014, na Gazeta do Paraná, as escolas municipais năo possuíam intérpretes, situaçăo que fazia com que tivessem que contar com o esforço e dedicaçăo de alunos e professores. A rede municipal de educaçăo possuía, em 2014 , "um total de 23 alunos haitianos matriculados no Ensino Fundamental e 9 matriculados em Centros Municipais de Educaçăo Infantil (CMEIS). Sáo 8 escolas e 8 CMEIS com alunos desta nacionalidade" (CRISTINA; LUZ, 2014, p. 01).

Segundo a Secretaria Municipal de Educaçăo de Cascavel, em 2018 o número de matrículas na rede, considerando Educaçăo Infantil, Ensino Fundamental, Anos Inicias e Educaçăo de Jovens e Adultos (EJA), era de 30.521. Nesse sentido, Grigoli (2018, p. 01) destaca que:

[...] crianças haitianas representam o maior número de estrangeiros que hoje frequentam escolas municipais de Cascavel. Cerca de 100 alunos estâo matriculados e desse total, mais de $90 \%$ sáo haitianos. A maior parte deles está matriculada nos $3^{\circ}$ e $4^{\circ}$ anos.

Já em relaçăo à rede estadual de ensino, o número de matrículas, no ano de 2018, 
era de 31.308, considerando um total de 42 escolas. Em razâo de esses dados serem referentes a matrículas no geral e nâo apontarem as nacionalidades dos alunos houve a necessidade de entrar em contanto com algumas escolas do município que forneceram dados quantitativos dos haitianos matriculados. A escolha das escolas se restringiu à regiâo oeste de Cascavel, tendo em vista o número de haitianos ali residentes.

Em 2018, no Colégio Estadual Professor Victório Emanuel Abrozino, o número de haitianos matriculados era de 4 alunos, sendo 3 no Ensino Fundamental e 1 no Ensino Médio. Já o Colégio Estadual Júlia Wanderley contava com 2 haitianos matriculados, sendo 1 no Ensino Fundamental e 1 no Ensino Médio. Por sua vez, no Colégio Estadual Padre Carmelo Perrone, aproximadamente 50 haitianos estavam matriculados em 2018, tanto no Ensino Fundamental como no Ensino Médio, nos três turnos.

Na Educaçăo de Jovens e Adultos (EJA), segundo dados do Núcleo Regional de Educaçăo de Cascavel, o número de matriculados no ano de 2018 era de 2.212 alunos, sendo 1.111 alunos no Ensino Fundamental - Fase II e 1.101 alunos no Ensino Médio. Nesse sentido, Grigoli (2018, p. 01) afirma que:

\begin{abstract}
Uma das alternativas buscadas pelo público estrangeiro para aprender o português é o CEEBJA (Centro de Educaçấo Básica para Jovens e Adultos). Atualmente, cerca de 20 estrangeiros estăo matriculados nessa modalidade de ensino e a maioria é de haitianos. "Săo matriculados nas variadas disciplinas, preferencialmente em Língua Portuguesa", explica a equipe do CEEBJA. No decorrer dos estudos, os alunos seguem as etapas previstas para a conclusâo da Educaçăo Básica.
\end{abstract}

Dessa forma, nota-se que apesar da falta de políticas públicas, que văo desde a ausência de treinamentos ou de contrataçăo de intérpretes para a inserçăo dos migrantes nas escolas, esses alunos estáo sendo inseridos no espaço educacional, em um esforço conjunto dos profissionais de educaçâo e dos próprios haitianos. Corroborando neste sentido, Alice L. Mattos, Cristina A. Sarturi e Leandro A. Borges (2015, p.68) afirmam que:

\footnotetext{
Partindo-se do pressuposto de que migrar é inerente a todos - haja vista a mobilidade ser um processo natural - e, portanto, um direito humano, deve ser assegurado, onde quer que seja, um local adequado e uma vida digna àqueles que decidem dar um novo rumo à sua vida ou sâo forçados a tanto. Nesse sentido é que as políticas públicas devem ser pensadas e propostas, de modo que o imigrante seja, de fato, sujeito de direitos e náo fique submetido a condiçôes desumanas - semelhantes ou, muitas vezes, piores - àquelas das quais está buscando melhoria.
}

Em conformidade com a questâo de açôes individuais e o esforço conjunto realizado, principalmente por professores e equipes pedagógicas, cabe mencionar a organizaçáo de um projeto com o objetivo de proporcionar aulas de tênis de mesa para haitianos no município de Cascavel em 2017. O projeto foi inspirado no jovem haitiano Edson Jean François, de 15 anos, que organizou na garagem de sua casa um centro de treinamento, utilizando uma mesa velha e chinelos e cadernos como raquetes. O projeto foi organizado pelo professor Edson Gavazzoni, e contou com a ajuda da comunidade que "doou as tábuas para que as mesas fossem construídas e ajudou na compra de outros materiais. Atualmente, mais de dez meninos participam do projeto" (BITTENCOURT, 2017, p. 01).

A Constituiçâo Federal do Brasil de 1988 estabelece, no caput de seu artigo 5, como um dos direitos e garantias fundamentais o da igualdade, garantindo tanto 
aos brasileiros quantos aos estrangeiros residentes no Brasil. Sob este contexto, entende-se que a igualdade refere-se à garantia de acesso a todas as oportunidades, as mesmas condiçôes de inserçâo, independentemente se brasileiros ou estrangeiros, ou seja, condiçóes de uma igualdade real. No entanto, o que se percebe na prática quanto à inserçăo dos imigrantes haitianos é que as várias açōes de inserçăo partem de açōes voluntárias, principalmente de instituiçôes religiosas e de educaçăo. Segundo o Padre Gelmino Costa (2012, p. 96):

Se analisada esta imigraçáo considerando a situaçăo dos imigrantes na origem, as dificuldades da viagem - uma verdadeira epopeia - e o início da inserçăo nas cidades brasileiras, os haitianos se tornaram um fato que pede reflexáo pelo conjunto da sociedade brasileira. Mostrou em primeiro lugar como é grande a distância entre a comoçấo e os discursos das açôes concretas. Nâo se pode ir ao Haiti dizendo que o Brasil acolheria bem os haitianos e fazê-los passar por tamanho sofrimento, quer na travessia, quer na chegada. Mostrou o anacronismo da própria política brasileira de imigraçăo. Mostrou as desavenças entre os poderes constituídos - municipal, estadual e federal - vivendo um jogo de empurra-empurra, um acusando o outro e todos lavando as máos. Mostrou que primeiro se deixa o prédio cair para depois ver o que fazer.

Outro desafio encontrado pelos haitianos para a inserçăo na sociedade brasileira é o aprendizado da língua portuguesa. Os haitianos sáo diglóssicos, ou seja, no Haiti coexistem duas línguas: o francês e o créole. Ao longo da história do Haiti a coexistência dessas duas línguas representou um demarcador social. Conforme afirma Grondin (1985, p.73):

O francês é somente a língua da elite. O créole é a língua própria da massa: serve para distinguir as massas sociais. 0 créole haitiano é uma criaçấo dos negros escravos do Haiti. Oriundos de centenas de grupos linguísticos diferentes, misturados entre si por seus captadores, vendedores, compradores, donos das plantaçóes, os escravos do Haiti tiveram que criar um meio de comunicaçáo oral e cultural entre si mesmos e entre eles e seus donos. Utilizando o francês, língua da colônia, como base criaram o créole.

A oficializaçăo das duas línguas o francês e o créole, somente foi estabelecida pela Constituiçāo haitiana de 1987.

A Constituiçăo haitiana de 1987 tornou co-oficiais o francês e o créole, obrigando o Estado haitiano a publicar todos os documentos oficiais nessas duas línguas. No momento, as leis, os códigos, os formulários, as peças administrativas ainda săo redigidas quase que exclusivamente em francês. A maioria dos funcionários tem um conhecimento limitado do francês e uma ignorância quase total da leitura e da escrita do créole que todos falam. Isto porque só depois deste diploma legal é que se começou a pôr em prática um esforço de padronizaçăo da escrita no Haiti (RODRIGUES, 2008, p. 5-6).

Rodrigues (2008) afirma que, atualmente, no Haiti aproximadamente 10\% dos haitianos conseguem se expressar mais ou menos corretamente nas duas línguas oficiais. Conforme o pesquisador:

No Haiti o créole é falado pela totalidade da populaçăo. Baseado na oralidade, sua transcriçăo na vida quotidiana, embora crescente, ainda é reduzida. Sua utilizaçăo escrita corresponde geralmente à afirmaçăo de uma identidade e a 
um posicionamento militante. O francês, por sua vez, é a língua da educaçâo, da administraçâo e da maioria dos meios de comunicaçâo (RODRIGUES, 2008, p. 189).

No decorrer da pesquisa observou-se que diversas açóes de promoçăo do ensino da língua portuguesa aos imigrantes haitianos. Merecem destaque duas iniciativas desenvolvidas na regiáo Norte do país, ambas em Porto Velho, município que chegou a abrigar cerca de 1.200 haitianos. A primeira, da Igreja Católica, que por meio de sua pastoral propiciou um curso de português básico ministrado por um haitiano que já havia aprendido a língua portuguesa. A segunda, uma iniciativa de 2011, implantada pelos pesquisadores Marília L. Pimentel e Geraldo C. Cotinguiba (2012, p. 101):

Por meio do projeto de extensăo supracitado, desde julho de 2011 ministramos aulas de português para os imigrantes. Já foram atendidos pelo projeto mais de 300 haitianos, sendo que, atualmente, há uma rotatividade grande, pois muitos começam o curso e desistem por três motivos, quais sejam: viajam para outros estados, começam a trabalhar à noite, ou mesmo os que acham que já aprenderam o suficiente. Deste modo, frequentam as aulas, hoje, cerca de 50 alunos.

No que se refere ao oferecimento de cursos de português no município de Manaus, as iniciativas ficaram a cargo de açōes voluntárias, de instituiçóes religiosas e dos próprios imigrantes. Conforme afirma o Padre Gelmino Costa (2012, p. 96):

\begin{abstract}
Toda tarefa de acolhida continuou por conta da Igreja Católica, do grupo Ama Haiti, de três pastores evangélicos e, ao final, também da Associaçăo dos Haitianos. Pessoas e entidades muito ajudaram e náo se pode deixar de nomear a Associaçáo Allan Kardec. Porém, os principais protagonistas de acolhida foram os próprios haitianos. Eles souberam acolher a muitos em seus quartinhos paupérrimos e limitados de tudo. Sempre cabe mais um nesses momentos. As doaçôes por parte do povo manauara também foram proporcionando subsídios importantes para a alimentaçăo e o vestuário. Com competência e eficiência atuaram e atuam as equipes de alimentaçăo, de saúde, de ensino da língua portuguesa, de cursos profissionalizantes e de emprego.
\end{abstract}

Por sua vez, na regiăo Sudeste, o município paulista de Santo André contava em 2015 com 700 haitianos. Para suprir a demanda pelo aprendizado da língua portuguesa, foi realizada uma parceria do poder público local com o SENAC (Serviço Nacional de Aprendizagem Comercial), que ofereceu um curso de português por meio do Programa Nacional de Acesso ao Ensino Técnico e Emprego (PRONATEC). Em 2014 e em 2015 já haviam sido atendidos 135 migrantes haitianos (BORBA; MOREIRA, 2016, p.458).

Em Cascavel, da mesma forma que em outras cidades brasileiras, foram identificadas várias iniciativas do ensino da língua portuguesa gratuitas para os imigrantes haitianos. Em 2012, por exemplo, um curso de português foi oferecido pelo Centro Universitário Fundaçăo Assis Gurgacz (FAG) e pela Secretaria Municipal de Educaçâo, por meio do Centro Educacional Paulo Freire, responsável pelo EJA (Educaçáo de Jovens e Adultos). 0 curso atendeu cerca de 40 haitianos que chegaram ao final de janeiro de 2012, para trabalhar nas obras da FAG e do Hospital Săo Lucas³ (GLOBO, 2012). Já no ano de 2016, uma açâo foi empreendida pela Escola Sagrada Família e, em 2017, pelo Colégio Estadual Padre Carmelo Perrone, situaçôes onde professoras voluntárias

3 O Hospital São Lucas é privado e vinculado à Fundação Assis Gurgacz. 
desenvolveram um projeto para o ensino da língua portuguesa para crianças e adultos haitianos.

O Colégio Estadual Padre Carmelo Perrone ofertou, no referido ano, o ensino do português por meio do Centro de Línguas Estrangeiras Modernas (CELEM). As classes eram organizadas em duas turmas com um total de 58 haitianos. 0 mesmo programa também é ofertado pelo Colégio Estadual Professor Victório Emanuel Abrozino, que possui uma turma com 30 haitianos matriculados.

Durante a pesquisa de campo realizada verificou-se que entre os entrevistados dois falavam inglês, além do créole e do francês, casos de Dykenlove John Marcelin e de Ronald Toussaint. Além disso, na pesquisa constatou-se que os imigrantes se comunicam com a língua materna quando estâo no coletivo, apesar de terem conhecimento da língua portuguesa, mesmo quando no ambiente estăo presentes brasileiros. Em relaçáo às mulheres haitianas, a pesquisa constatou que elas possuem algumas barreiras em participar dos projetos que oferecem aulas de português. De acordo com Ferreira (2017):

Entre todas as fragilidades da migraçâo, tem a questăo das mulheres, elas náo buscam aprender a língua, elas estăo ficando em casa, elas estăo ficando à margem desse processo de inserçăo, na comunidade e no trabalho, năo săo todas, mas muitas delas.

Jesula Fils Aimé, 44 anos, solteira, residente há 14 meses em Cascavel, revelou que no curso de idiomas que participava, a maioria da turma é frequentada por homens. Embora esta desproporçăo também esteja relacionada com a grande diferença entre o número de homens e mulheres imigrantes, há indicadores que fatores ligados às relaçôes de gênero estejam por trás da inserçâo diferenciada.

Estou aprendendo pela televisăo e nos sábados vou ao Colégio Sagrada Família com a professora Terezinha, há bastantes alunos haitianos homens, mas só duas alunas mulheres e eu, as mulheres só querem trabalhar (Narrativa $n^{\circ} 9$ - pesquisa de campo, 2017).

Nesse sentido, Marília L. Pimentel e Geraldo C. Cotinguiba (2012) afirmam que:

[...] o maior entrave tem sido registrado pelas mulheres, especialmente pelo fato da barreira linguística, pois majoritariamente falam apenas o créole e isso tem dificultado a inserçăo no mercado de trabalho. Acrescente-se o fato de năo frequentarem o curso de português; parece haver uma "resistência" em aprender o nosso idioma, por razōes que ainda náo conhecemos. Em geral, as haitianas trabalham como diaristas, empregadas domésticas ou em restaurantes e lanchonetes. Muitas foram demitidas por conta da barreira linguística (PIMENTEL; COTINGUIBA, 2012, p. 103).

Segundo Pimentel e Cotinguiba (2012), na maioria dos casos as mulheres haitianas residentes em Porto Velho possuem menor grau de escolaridade do que os homens e devido a um conjunto de regras sociais as mesmas săo responsáveis pelo lar e pelos filhos, enquanto aos homens cabe o sustento da família. Nesse sentido, Rosa (2006, p. 22) afirma que:

A produçăo de conhecimento e a instauraçăo de uma educaçăo formal em uma língua colonial é um dos principais geradores das desigualdades instauradas no Haiti, já que săo as mulheres monolíngues (falantes apenas do créole) e sem qualquer tipo de 
acesso à educaçâo formal constituem o grupo de maior vulnerabilidade social, pois embora os homens também compartilhem do mesmo grau de desamparo social, eles conseguem migrar em um percentual significativamente maior do que as mulheres, seja para a República Dominicana, para o trabalho no plantio e colheita de canade-açúcar ou para a construçăo civil, ocupaçōes marcadamente masculinas, seja para os Estados Unidos ou Canadá, porque gozam de uma rede de solidariedade muito mais consolidada nos países de destino, ao passo que as mulheres haitianas encontram muito mais dificuldades no processo migratório, pois năo encontram o mesmo suporte que seus compatriotas. Isto ocorre devido à fragilidade nas redes de cooperaçâo femininas de incentivo à imigraçâo, à baixa exposiçâo das mulheres à vida pública, obrigando-as à dedicaçâo quase que exclusiva à reproduçâo familiar, limitando as chances de sobrevivência social fora do lar e do seu próprio país.

Mezzadra (2005) aponta para o fato de que a migraçăo feminina năo se deve apenas às condiçôes econômicas de mulheres solteiras, viúvas ou divorciadas, mas é uma decisăo consciente de quem busca abandonar uma sociedade dominada pelo patriarcado. A reflexăo sobre as questóes de gênero conduz a um campo vasto, que excede os limites do alcance da pesquisa realizada para o presente trabalho. Desse modo, náo foi possível realizar uma análise mais aprofundada sobre tais problemáticas, mas apenas aferir que as posiçóes sociais reservadas para homens e mulheres na cultura do Haiti interferem na forma em que ocorre a inserçâo social diferenciada na sociedade brasileira.

Diferente daquilo que se refere à estrutura de acolhimento primária, observa-se uma preocupaçâo um pouco maior das redes de ensino em absorver a demanda composta pelos imigrantes, auxiliando-os no processo de inserçấo social por meio do ensino do idioma, principalmente. Contudo, o oferecimento do ensino do português para os imigrantes náo se apresenta como uma política pública generalizada no território nacional, garantindo certa heterogeneidade ao serviço. Além disso, as diferenças de gênero também surgem de maneira importante no processo de inserçăo na sociedade brasileira e, nesse contexto, as fronteiras étnicas existentes entre os imigrantes haitianos e os nacionais recebem reforços significativos. A própria nacionalidade, o idioma e a forma pela qual a cultura haitiana determina o lugar social da mulher e do homem dificultam a superaçâo dos obstáculos encontrados durante a migraçâo.

\section{RELIGIÃO E XENOFOBIA NO PROCESSO DE INSERÇÃO SOCIAL}

A pesquisa de campo realizada para o presente trabalho demonstrou que a observaçấo do fluxo migratório e da inserçăo dos migrantes na sociedade receptora exige o estudo de várias facetas do fenômeno. Desse modo, é preciso levar em conta as perspectivas e percepçôes que estâo interligadas ao processo de inserçâo do imigrante haitiano no Brasil. Questóes como o acolhimento no país, as formas de organizaçóes estabelecidas, a cultura, as habitaçóes, o aprendizado da língua, o acesso à educaçâo. Nessa perspectiva, cabe destacar as questôes relacionadas ao preconceito, bem como à religiosidade.

O fluxo dos imigrantes haitianos às cidades brasileiras tem provocado mudanças socioculturais e estruturais nestas cidades e no cotidiano da populaçăo local, pois os sujeitos que migram carregam consigo todo um conjunto simbólico. Todavia, imigrantes e sua cultura nem sempre săo bem recebidos no território brasileiro. Nesse 
sentido, durante a pesquisa de campo foram registradas manifestaçóes de preconceito e xenofobia, por exemplo, em inúmeras pichaçóes de repúdio aos haitianos em estabelecimentos comerciais, em pontos de ônibus e muros do centro de Cascavel. Também foram registrados casos de violência física em diferentes pontos do país, como o episódio que envolveu seis haitianos na Baixada do Glicério, Săo Paulo, em agosto de 2015. Na ocasiăo, jovens passaram de carro efetuando disparos com armas de chumbinho e xingando os haitianos de ladrōes de empregos (LACERDA, 2016).

Outro episódio de violência contra migrantes haitianos ocorreu em 14 de maio de 2016, na cidade de Foz do Iguaçu, quando um haitiano de 33 anos, estudante da Universidade Federal da Integraçăo Latino-Americana, foi agredido no centro da cidade por um grupo de jovens, durante a madrugada. De acordo com o imigrante, ele estava se deslocando para a rodoviária com o objetivo de viajar para a cidade de Cafelândia para visitar o filho quando foi agredido por um grupo de pessoas que estavam em um bar. Segundo o estudante, foram proferidos insultos racistas e xenófobos, além da agressâo física (GLOBO, 2016).

Segundo Maciel (2016), no ano de 2015, as denúncias de xenofobia no Brasil cresceram $\mathbf{6 3 3 \%}$ em relaçăo ao ano anterior. De acordo com a Secretaria Especial de Direitos Humanos, os principais alvos do preconceito sáo os haitianos, representando $26,8 \%$, seguidos dos migrantes de origem árabe ou de religiăo muçulmana $(15,45 \%)$. Em relação ao fluxo migratório haitiano às cidades brasileiras e às manifestaçóes de repulsa, dois pontos merecem ser analisados: o fato de serem estrangeiros e o fato de serem negros. Para Goffman (1982) e Bauman (1998), a relaçóes étnicas que marcam este tipo de encontro guardam uma situaçáo onde o outro é desconhecido, o que provoca o medo e a repulsa, podendo originar reaçóes hostis que, por sua vez, podem causar a estigmatizaçâo.

Um dos pontos observados durante o percurso da pesquisa de campo refere-se a expressōes pejorativas utilizadas por algumas mídias em relaçăo ao fluxo migratório haitiano ao Brasil, que acabam por manter ou até mesmo inflamar a estigmatizaçáo sobre o Haiti e os haitianos.

\begin{abstract}
Algumas expressōes pejorativas como "Haitianos invadem o Brasil", "Haitianos fogem da miséria do Haiti", "Haitianos morrem de AIDS" foram corriqueiras nos meios de comunicaçấo brasileiros. As caracterizaçôes pejorativas exacerbaram a imagem predominantemente do Haiti como um país pobre e miserável, trazendo à tona a importância de se relacionar essas imagens com processos de incorporaçáo e exclusăo de imigrantes haitianos na sociedade brasileira. A chegada de milhares de haitianos ao país evidenciava um forte sentimento de rejeiçăo à imigraçăo haitiana por boa parte das matérias veiculadas na mídia brasileira, por ser indesejada (HANDERSON, 2015, p. 149).
\end{abstract}

Segundo Samora (2015), as mídias, de uma forma geral, contribuem para a institucionalizaçăo de comportamentos sociais por meio de seus discursos. Em outras palavras, "o modo como as matérias jornalísticas sâo construídas e enunciadas promove a formaçăo de representaçóes individuais ou de grupos e comunidades" (SAMORA, p. 2015 p.66). De acordo com Silva (2015, p. 127), tais açóes da mídia local e nacional săo na verdade tentativas de se "construir um estigma contra um determinado grupo de imigrantes para responsabilizá-los das mazelas já existentes na sociedade local". Corroborando com tal entendimento, Bauman (1999, p. 84) afirma que: 
As imagens de desumanidade que dominam as terras onde vivem possíveis migrantes vêm, portanto, a calhar. Elas reforçam a determinaçăo que náo dispóe de argumentos éticos e racionais a apoiá-la. Ajudam os habitantes locais a permanecerem locais, ao mesmo tempo em que permitem aos globais viajar com a consciência limpa.

Dessa forma, observa-se que muitos haitianos se sentem discriminados tanto pela sua condiçăo de imigrante, quanto pela sua cor. Nesse sentido, cabe registrar o depoimento de Dykenlove John Marcelin, 22 anos, solteiro:

Foi um pouco difícil até ter um amigo pra me ajudar, mas já sofri muito por causa do preconceito, mas isso falei pra todo mundo que tem preconceito, que năo adianta que eu náo vou mudar minha cor, eu nasci negro e vou morrer negro. Eu sofri muito até por que eu trabalhei numa loja de sapatos, o cara năo me tratava bem e daí resolvi sair da loja.

O tipo de tratamento discriminatório que Dykenlove John Marcelin descreve se reproduziu em um caso noticiado pela mídia de Cascavel. Uma internauta registou um vídeo que mostrava uma confusăo entre uma atendente de loja e um grupo de haitianos. A loja presta serviço de transferência de moedas para o exterior e no episódio a atendente gritava e ameaçava năo realizar o atendimento aos imigrantes que formavam fila no local, demonstrando total desrespeito pelos haitianos (WRONSKI, 2015).

As narrativas apresentadas demonstram o estabelecimento do estigma, do preconceito aos imigrantes negros, como se fossem invasores, que ocuparăo vagas de empregos dos supostos nativos e que usufruirăo de serviços públicos. Nesse sentindo, Cotinguiba e Pimentel (2012) atentam para o fato de que no Brasil, desde 2010, por um lado vem se consolidando a ideia de que o haitiano é pobre, sem qualificaçăo profissional, que precisa de ajuda porque migrou fugindo do terremoto e por isso deve ser acolhido, enquanto que por outro lado vem sendo cunhada a imagem do "invasor" que precisa ser expulso, pois onera os cofres públicos. Nesse sentido, Lima e Vala (2004, p. 404), asseveram que:

As atitudes contra os negros decorrem menos da percepçáo por parte do grupo dominante de que os negros constituem uma ameaça econômica concreta e mais da percepçăo dos negros como uma ameaça simbólica, ameaça aos valores e à cultura do grupo dominante. Os negros sâo percebidos como violadores dos valores que mantêm o status quo das relaçóes inter-raciais.

De acordo Lima e Vala (2004), atualmente novas formas preconceito e racismo coexistem com as teorias tradicionais, o que resultou nas teorias do racismo moderno, racismo simbólico, racismo aversivo, racismo ambivalente, racismo cordial e do preconceito sutil. Para os referidos autores, os sentimentos que caracterizam os racistas aversivos năo săo sentimentos de hostilidade ou de ódio, mas sentimentos de desconforto, nervosismo, ansiedade e medo em relaçăo a pessoas negras. Nesse sentido, cabe destacar o depoimento de Jesula Fils Aimé, 44 anos, solteira, residente desde 2016 na cidade de Cascavel. Ela explicita que "existem pessoas que nâo querem nem sentar com a gente porque somos pretos, mas também tem gente boa aqui, que nos ajuda".

Diante da fala da interlocutora, outro ponto a ser destacado é referente à mulher negra e imigrante. Apesar do aumento do fluxo migratório de mulheres na 
contemporaneidade, elas compóem um quadro de maior vulnerabilidade no país receptor. Segundo Dutra (2016, p. 181):

O entrecruzamento das condiçóes de classe, gênero e etnia condena o coletivo de mulheres migrantes trabalhadoras a uma situaçáo de vulnerabilidade social acentuada pela concentraçáo delas no mercado de trabalho informal e, consequentemente, pelo acesso desigual a recursos materiais e à documentaçáo que lhes permita desempenhar seus trabalhos em situaçăo regular.

Outra teoria de racismo analisada refere-se ao racismo cordial, por ter sido identificada durante as entrevistas com os imigrantes haitianos. Conforme Turra e Venturi (1995), o racismo cordial é tipicamente brasileiro, sendo caracterizado por uma polidez superficial nas relaçóes interpessoais por meio de piadas, ditos populares e brincadeiras raciais. Nesse sentido, cabe destacar o relato de Ronald Toussaint, que afirmou ter se acostumado com as brincadeiras de cunho racial proferidas pelos brasileiros: "já estou no Brasil há três anos, entáo já estou acostumado com os caras que me xingam e brincam comigo, estou no Brasil, fazer o que né?!".

Săo muitos os casos de racismo vinculados na imprensa local, um deles, que merece destaque, envolveu questóes de aluguel de imóveis para haitianos e foi descrito por Monteiro (2014).

Nove haitianos que moram em dois apartamentos em um prédio na Rua Costa e Silva afirmam que foram ameaçados. 0 agente penitenciário teria dito ser um policial, apontado arma e determinado que eles deixassem o local até 10 de março, se náo seriam mortos. [...] 0 pai dele teria construído o prédio. Já a síndica estaria desligando o gás para deixar os haitianos sem serviço (MONTEIRO, 2014, p. 01).

Nesta perspectiva, Essed (1991) contextualiza que as novas formas de preconceito e racismo se situam principalmente no nível das relaçōes interpessoais e referem-se a comportamentos de discriminaçăo na vida cotidiana das pessoas. Em conformidade com essa problemática, merece destaque a pesquisa de Gomes (2017), que utilizou como metodologias a observaçấo participante e as narrativas produzidas por meio de entrevistas realizadas com dois grupos de haitianos em Florianópolis - um grupo de trabalhadores e um grupo de estudantes.

Embora năo tenhamos tido muitos relatos sobre a vivência de práticas discriminatórias, pudemos observar durante nossas inserçóes no campo algumas cenas de evidente segregaçăo e exclusăo: em uma praça central da cidade, comumente utilizada pelos trabalhadores durante a pausa do almoço, os lugares com sombra eram visivelmente tomados, em sua maioria, por brancos e brasileiros; analogamente, no refeitório da universidade a divisăo por raça e nacionalidade ocorria de modo evidente. Observável em espaços específicos, esse tipo de segregaçăo também se reproduzia na geografia urbana da capital: convidados a trabalhar em uma determinada fábrica, cerca de 60 haitianos foram alojados em regiăo afastada do centro da cidade, à beira de uma estrada e a ao menos 40 minutos de qualquer tipo de serviço socioassistencial (GOMES, 2017, p. 7).

Diante disso, percebe-se que independentemente se sutis, veladas, explícitas ou agressivas, as manifestaçôes de preconceito e racismo ocorrem cotidianamente com os imigrantes haitianos residentes no Brasil.

Outro elemento visualizado durante a pesquisa de campo corresponde ao fenômeno 
religioso, que pode nos auxiliar no entendimento de questóes referentes aos desafios encontrados pelos imigrantes haitianos na inserçáo social no Brasil. Embora năo seja um objetivo inicialmente previsto para o presente trabalho, a temática acabou emergindo devido à importância das diferentes religiôes no processo de construçâo das redes sociais de recepçâo no Brasil e também devido aos preconceitos existentes em relaçăo ao vodu. No Haiti duas religiôes sâo predominantes ao longo da história, o cristianismo, introduzido pelos colonizadores ocidentais, e o vodu, que só foi reconhecido como religiăo no país em 2003. Nesse sentido, Grondin (1985, p. 85) esclarece:

O cristianismo no Haiti, católico ou protestante - praticado e difundido por estrangeiros ocidentais e mulatos em sua maioria carregados de dogmas da filosofia ocidental, instituído em escolas, colégios e hospitais, e pregando contra instituiçóes sociais nacionais como o plaçage (uniăo matrimonial sem contrato oficial) veiculou um novo sistema de referência que desvaloriza os costumes e as estruturas tradicionais dos haitianos náo ocidentalizados, levando à alienaçáo cultural e a à identificaçăo com branco, com o estrangeiro, com o urbano, com a elite. A religiâo católica, profundamente estrangeira com relaçăo a tudo o que é africano, apresentase como a religiâo da elite; ao ser a religiâo oficial e da civilizaçăo ocidental, é a religiáo dos brancos. Ocidental em seu conteúdo e em suas expressōes rituais, transmite a ideologia de que a verdadeira civilizaçăo é a civilizaçăo ocidental, da mesma forma como trata de transmitir a ideia de que a verdadeira língua é a francesa. A Igreja Católica no Haiti é um instrumento homogeneizante da elite e desarticulador das massas.

Uma pesquisa realizada no Haiti apontou que 4.555.000 de haitianos săo cristăos. Destes, 3.797.000 sâo católicos, 400.000 protestantes e 100.000 espíritas (MELTON; BAUMAN, 2010). Durante a pesquisa de campo, os entrevistados se declararam católicos, evangélicos ou mesmo náo praticar nenhuma religiâo, náo havendo entre eles praticantes do vodu. Cabe destacar os relatos de Dykenlove John Marcelin e Jesula Fils Aimé, respectivamente:

Sou evangélico, eu toco na igreja, canto também, năo prego, porque năo é minha funçăo, já viajei pra Foz do Iguaçu, Toledo, Marechal Cândido Rondon e Vera Cruz do Oeste, toco quando necessitam e quando a igreja convida.

Sou evangélica, há seis meses, estou participando dos cultos, com meus irmáos haitianos, todos os domingos. O culto é realizado por um haitiano, o Emílio, em créole.

De acordo com a Cáritas, ocorrem missas mensais, celebradas em créole, uma açăo conjunta da referida organizaçáo com a Pastoral do Migrante. Nesse sentido, Ferreira (2017) esclarece que:

Essa acolhida por nós, enquanto Cáritas e Pastoral do Migrante, aos imigrantes haitianos em todo um processo coletivo é importante, tanto que a Pastoral agora se fortaleceu, tem um padre haitiano, o Wilnie Jean, que vem para fazer essa aproximaçấo com o Haiti, por estar celebrando as missas em créole e terem organizado um coral.

No dia 05 de março de 2017, com o apoio da Pastoral do Migrante, ocorreu em Cacavel uma missa aberta à populaçăo local, celebrada em créole. Além das missas em créole, há também igrejas voltadas especificamente à comunidade haitiana. Conforme 
Fellet (2013), a igreja Assembleia de Deus da cidade de Porto Velho construiu um templo para atender os imigrantes haitianos.

A Assembleia de Deus foi a primeira na cidade a erguer um templo só para o grupo. A maioria dos fiéis passou a frequentá-la após se mudar para Porto Velho, seduzida pelos cultos em créole, a língua mais falada do Haiti. Quem conduz as cerimônias é o haitiano Pierrelus Pierre. Antes de migrar para o Brasil, ele já era pastor da Assembleia de Deus na República Dominicana (FELLET, 2013, p.01).

Já em relaçâao à prática do vodu, Couto (2016) afirma que entre os imigrantes haitianos nâo se evidenciou sua presença em território brasileiro.

No Brasil, o fato de a comunidade haitiana ainda encontrar-se em trânsito pelo país, as características da religiosidade vodu ainda vigoram num âmbito bastante particular da comunidade de imigrantes, embora no Brasil eles encontrem uma referência bastante próxima ao vodu no Candomblé Jeje, essa interculturalidade ainda năo se evidenciou (COUTO, 2016, p. 165).

Nesse contexto, nota-se que o fato do imigrante se definir como católico ou evangélico, embora necessariamente nâo seja exótico, pois a maioria da populaçâo no Haiti se denomina cristă, pode ser entendida como uma estratégia de inserçăo na regiâo receptora, principalmente pelo fato das instituiçóes religiosas estarem cumprindo um papel fundamental no processo de acolhimento e inserçăo dos haitianos. Para Ribeiro (2016):

O que se observa é que essa identidade ligada ao vodu se transforma, se adapta, se encuba atrás das exigências e tradiçôes de um país estrangeiro pelo receio de que possa haver rejeiçăo ou perseguiçáo ou intolerância religiosa. Ou simplesmente por năo haver identificaçăo com o espaço sociocultural em que se está inserido (RIBEIRO, 2016, p. 114).

A religiấo atua diretamente no processo de inserçấo e de formaçăo de sociabilidades no país de destino. A prática religiosa, seja ela a mesma do país de origem ou a incorporaçấo da religiâo do país de destino, torna-se ponte de inserçâo social na nova sociedade e ao mesmo tempo de continuidade na manutençăo de laços simbólicos com o país de origem. A pesquisa de campo atestou a importância das redes no fluxo migratório, enfatizando as múltiplas relaçōes que săo estabelecidas entre os imigrantes, tanto no país de origem quanto no país de destino, bem como as redes formadas por instituiçôes de cunho confessional e as ONGs. Conforme Silva (2017, p.100), "embora diferentes redes possam estar imbricadas em processos migratórios, vale notar que cada uma delas tem finalidades específicas e formas estratégicas de atuaçăo".

Para Massey (1990), as redes migratórias compóem um conjunto de laços sociais que une migrantes e năo-migrantes em uma complexa teia de papéis sociais e relacionamentos interpessoais, estes mantidos por meio de um quadro informal de expectativas e comportamentos predeterminados (MASSEY, 1990). Corroborando nesse sentido de teias, Elias (1994, p. 35) afirma que:

Para ter uma visăo mais detalhada desse tipo de interrelaçăo, podemos pensar no objeto de que deriva o conceito de rede: a rede de tecido. Nessa rede, muitos fios isolados ligam-se uns aos outros. No entanto, nem a totalidade da rede nem a forma assumida por cada um de seus fios podem ser compreendidas em termos de um único 
fio, ou mesmo de todos eles, isoladamente considerados; a rede só é compreensível em termos da maneira como eles se ligam, de sua relaçăo recíproca.

Nesta perspectiva, Nína (1995) esclarece que as redes podem se constituir por grupos distintos, endo e exogrupais. Os grupos denominados endo seriam os formados pelos imigrantes que possuem vínculos étnicos, culturais, religiosos ou linguísticos, podendo proporcionar apoio afetivo, material e informativo sobre o local de destino. Enquanto os grupos exogrupais podem apresentar laços formais ou nâo, que vinculam os imigrantes com o país receptor. Nesse caso, săo exemplos as igrejas, ONGs, associaçōes filantrópicas e grupos ativistas de direitos humanos.

Durante a pesquisa de campo foi possível constatar que as redes sociais desempenham papéis importantes na gestăo do fluxo migratório haitiano. Nesse sentido, Portes e Böröcz (1989, p. 612) afirmam que:

Redes construídas pelo movimento e contato de pessoas através do espaço estāo no centro de microestruturas que sustentam a migraçăo ao longo do tempo. Mais do que cálculos individuais de ganho, é a inserçăo das pessoas nestas redes que ajuda a explicar propensôes diferenciais à migraçăo e o carácter duradouro dos fluxos migratórios.

Na ausência de políticas públicas de acolhimento e recepçăo voltadas aos imigrantes no Brasil, as redes têm desempenhado papéis importantes que, em grande medida, săo realizados por grupos privados, confessionais ou laicos. Segundo Silva (2017, p.100), "a ampla rede de assistência e orientaçâo foi, na verdade, mais um agente facilitador da mobilidade haitiana pelo Brasil, na medida em que os imigrantes usufruíram de sua ampla estrutura para resolver questōes mais imediatas".

As redes contribuem também na permanência na regiâo de destino à medida que auxiliam na inserçáo cultural, laboral, religiosa e social dos imigrantes. Em Cascavel, foram constatadas várias açōes nesse sentido. Muitas foram empreendidas pela Cáritas, que oferece o ensino do português, cursos de artesanato, sessôes de venda dos produtos resultantes dos cursos, além de ter organizado o Fórum dos Haitianos, bem como o $1^{\circ}$ Festival da Cultura Haitiana e, juntamente com a Pastoral do Migrante, a celebraçăo de missas em créole. Corroborando tal entendimento, Tilly (1990, p. 86), afirma que:

As redes também transformam as categorias existentes. Os migrantes levam consigo suas identidades étnicas que se alteram no contexto de migraçăo, nas relaçóes com a sociedade de destino e com outros grupos de migrantes. Assim, alguns elementos de identidade do país de origem sáo eleitos, negociados e reconstruídos no contexto de migraçăo. Portanto, ao invés de um "transplante" coletivo, há uma recriação seletiva de laços sociais.

Săo inúmeros os desafios e problemas encontrados pelos haitianos no processo de inserçăo na sociedade brasileira. Eles văo desde o aprendizado do português, ao acesso à educaçăo, habitaçáo, até situaçôes envolvendo preconceito e racismo. Dessa forma, as redes, sejam elas sociais, migratórias ou de acolhimento, săo de grande importância para o enfrentamento de tais problemáticas, pois servem de apoio na recepçăo, na superaçăo dos problemas concretos vivenciados, na busca da legalizaçáo da situaçáo no país e na forma pela qual os conflitos existentes sâo apreendidos e resolvidos. 


\section{CONSIDERAÇÕES FINAIS}

Acompanhar e analisar os fluxos migratórios, pensar sobre os processos de inserçăo e sobre a importância das redes sociais necessariamente possibilita avanços no entendimento dos processos de construçāo das fronteiras étnicas. O conjunto de estereótipos que marcam a comunidade haitiana que chegou ao Brasil ao longo dos últimos dez anos, somado ao conjunto de preconceitos manifestados pelos brasileiros, garantem ao fenômeno composto pela imigraçâo haitiana uma situaçăo ideal de reflexăo. O Haiti corresponde a um dos poucos países do continente americano colonizado por franceses, um país negro, marcado por uma história de lutas, ditaduras e desastres ambientais, fatos que explicitam um perfil populacional idealizado e que é preconcebido nas sociedades receptoras.

Nesse contexto, é possível encontrar de maneira idealizada um estereotipo pré-definido de imigrante haitiano: negros, fortes, passivos, praticantes de vodu, poliglotas e pobres. Muitas vezes a imagem que o brasileiro médio guarda em seu imaginário a respeito dos escravos africanos utilizados no processo de colonizaçăo portuguesa é transferida para os haitianos contemporâneos com incrível facilidade, sem nenhuma problematizaçâo. Contudo, estas características que supostamente estabeleceriam os limites de uma comunidade étnica náo correspondem exatamente ao que se encontra nas pesquisas realizadas. Em grande medida, todas estas características expressas servem como rótulos para diferenciar e justificar açôes sociais, estabelecendo possíveis fronteiras entre brasileiros e imigrantes haitianos.

Todavia, fronteiras náo correspondem exatamente a limites pré-definidos, mas a pontos de contatos fluidos, flexíveis, que se modificam historicamente por interferência de elementos estruturais e individuais. Cabe ressaltar que as fronteiras sâo relaçôes de imposiçăo, de aceitaçăo, de conflito e de civilizaçóes. As relaçôes entre as comunidades de imigrantes e os nacionais săo cotidianamente construídas. Assim, analisar o processo de inserçâo e as redes corresponde a um esforço que transborda a localidade e se estende para outras possibilidades e para outras fronteiras.

Como destacou Barth (1988), entre as diferentes formas de interaçâo há algumas estratégias relacionais e de construçăo da própria identidade étnica que sáo reconhecidas no caso estudado. A açăo dos imigrantes, ao buscarem as redes religiosas de recepçấo, explicita o reconhecimento, por parte dos imigrantes, das diferenças existentes entre as identidades étnicas e também das condiçôes concretas de sobrevivência. Este movimento poderia descartar uma das estratégias existentes na definiçấo das identidades étnicas: o isolamento. A identidade é construída por meio da relaçấo com o outro, seja através das tentativas de aproximaçăo, concorrência ou de isolamento. Neste último caso, a comunidade étnica reconhece, simultaneamente, as diferenças entre os grupos, mas também sua autossuficiência, buscando o fortalecimento de suas supostas raízes, suas tradiçōes e a sua própria endogenia.

Contudo, a pesquisa de campo demonstrou que estas estratégias nâo săo puras. Os grupos étnicos, ao desenvolverem manifestaçôes culturais e políticas, năo apenas buscam resgatar aspectos tradicionais do Haiti, mas também elementos que possam auxilia-los em como se posicionar diante das relaçôes. Ao mesmo tempo em que a construçăo de uma associaçăo de imigrantes possibilita um fortalecimento interno de aspectos que marcariam a identidade dos haitianos, ela também permite o surgimento 
de um novo agente político com potencialidade de discussăo e debate com o poder público. Desse modo, a organizaçăo dos haitianos em uma única instituiçăo năo representa apenas um esforço de autoreproduçáo por meio de atividades culturais realizadas, como os festivais culturais ou um programa de rádio, mas o nascimento de um agente representativo que possa estabelecer um diálogo mais agudo com os gestores governamentais.

Por outro lado, os esforços em aprender o idioma, em frequentar o sistema de ensino e até mesmo de participar nas comunidades religiosas podem ser entendidos, simultaneamente, como estratégias de aproximaçăo e de apreensâo da cultura do outro, mas também como esforços que permitiriam melhores condiçōes de inserçáo e de negociaçâo cotidiana nas cidades receptoras. Aprender o idioma e ocupar os espaços da populaçăo nacional năo corresponde exclusivamente a uma tentativa de inserçấo cultural e de adaptaçấo, mas também de apreensâo de ferramentas que possibilitariam o estabelecimento de relaçōes mais equilibradas entre os diferentes grupos étnicos. Enfim, as estratégias de inserçâo e de construçăo das identidades năo săo puras, elas se misturam e possibilitam a existência das idiossincrasias. 


\section{REFERÊNCIAS}

APPADURAI, A. Dimensóes culturais da globalizaçăo. Lisboa, Portugal: Teorema, 2004.

ARAUUJO, José R. de Campos. Políticas públicas, estruturas estatais e migraçōes no Brasil. In: Imigraçăo Haitiana no Brasil. Jundiaí: Paco Editorial, 2016.

ARRUDA, Aline Maria Thomé. A relaçăo entre o Estado e a imigraçăo: aspectos pertinentes para análise dos casos brasileiro e canadense. Cadernos OBMigra, v.1, n.3, 2015.

ASSSIS, Gláucia de Oliveira; MAGALHĀES, Luiz F. A. Migrantes indesejados: A “diáspora" haitiana no Brasil e os desafios à política migratória brasileira. In. SILVA, Sidney A.; ASSIS, Gláucia O. Em busca do Eldorado: 0 Brasil no contexto das migraçóes nacionais e internacionais. Manaus: EDUA, 2016.

BARTH, Fredrik. Grupos étnicos e suas fronteiras. In:POUTIGNAT, P. eSTREIFF-FENART, J. Teorias da etnicidade. Sâo Paulo: Unesp, 1998.

BAUMAN, Zygmunt. 0 mal-estar da pós-modernidade. Rio de Janeiro: Jorge Zahar, 1998.

Globalizaçăo: as consequências humanas. Rio de Janeiro: Jorge Zahar, 1999.

BHABHA, Homi K. 1998. O Local da Cultura. Traduçăo: Myriam Ávila, Eliana LL Reis e Gláucia R. Gonçalves. Belo Horizonte: Editora UFMG.

BITTENCOURT, Cícero. Haitiano improvisa tênis de mesa com chinelos e inspira projeto social no Paraná. G1 Globo. 15 dez. 2017. Disponível em: https://g1.globo.com/ pr/oeste-sudoeste/noticia/haitiano-improvisa-tenis-de-mesa-com-chinelos-e-inspira-projeto-social-no-parana.ghtml. Acesso em: 12 jun. 2018.

BORBA, Janine H. O. M. de; MOREIRA, Julia B. Integraçăo local de haitianos em Santo André: integraçăo entre poder público municipal e entidades religiosas. In: BAENINGER, Rosana; PERES, Roberta et al. Imigraçăo Haitiana no Brasil. Jundiaí: Paco Editorial, 2016.

COSTA, Gelmino A. Haitianos em Manaus: dois anos de imigraçăo - e agora! Travessia Revista do Migrante, Sáo Paulo, n. 70, 2012. p. 91-99.

COTINGUIBA, Geraldo Castro; PIMENTEL, Marília Lima. Apontamentos sobre o processo de inserçăo social dos haitianos em Porto Velho. Travessia - Revista do Migrante, Săo Paulo, ano 25, n. 70, p. 99-106, jan./jun. 2012.

.Wout, raketè, fwontyè, ampil, mizè: reflexóes sobre os limites da alteridade em relaçăo à imigraçăo haitiana para o Brasil. Universitas Relaçōes Internacionais, Brasília, v.12, n1. P. 73-86, jan/jun 2014.

COUTO, Kátia. Do caribe para a Amazônia: a migraçăo fomentando a conexăo entre duas regiôes. In. SILVA, Sidney A. ASSIS, Glaucia O. Em busca do Eldorado: 0 Brasil no contexto das migraçóes nacionais e internacionais. Manaus: EDUA, 2016. 
CRISTINA, Aline; BIANCO, Alini. Haiti Universal: agora eles estăo sintonizados. Central Gazeta de Notícias, Cascavel-PR, 22 jun. 2014. Disponível em: https://cgn.inf.br/noticia/95627/haiti-universal-agora-eles-estao-sintonizados. Acesso em: 1 jan. 2018.

CRISTINA, Aline; LUZ, Bruna. B. da. Sem intérpretes, escolas contam com dedicaçăo de alunos haitianos. Central Gazeta de Notícias, Cascavel-PR, 13 nov. 2014. Disponível em: https://cgn.inf.br/noticia/113034/sem-intaerpretes-escolas-contam-com-dedicaaaao-de-alunos-haitianos. Acesso em; 01 jan. 2018.

DANTAS, Sylvia D. Culturas em Xeque e o Desafio Psicológico de Ser entre Dois Mundos: biculturalismo entre Brasil e Japáo. In. FERREIRA, Ademir Pacelli.

EBERHARDT, Leonardo D. Haitianos em Cascavel, Paraná: história, trabalho e saúde. Dissertaçăo de Mestrado. Fundaçăo Oswaldo Cruz, 214 f. Rio de Janeiro: 2017.

FELLET, Joâo. Igrejas Evangélicas disputam imigrantes haitianos em Rondônia. BBC. 3 jul. 2013. Disponível em: https://www.bbc.com/portuguese/noticias/2013/07/130701_ haitianos_rondonia_bg. Acesso em: 28 abr. 2018.

GLOBO. Haitiano é vítima de agressăo no centro de Foz do Iguaçu no Paraná. G1 Globo. 16 maio 2016. Disponível em: http://g1.globo.com/pr/oeste-sudoeste/noticia/2016/05/ haitiano-e-vitima-de-agressao-no-centro-de-foz-do-iguacu-no-parana.html. Acesso em 2 jun. 2018.

GLOBO. Haitianos refugiados que trabalham em Cascavel aprendem português. G1 Globo. 3 abr. 2012. Disponível em: http://g1.globo.com/pr/parana/noticia/2012/04/ haitianos-refugiados-que-trabalham-em-cascavel-aprendem-o-portugues.html. Acesso em: 2 jun. 2018.

GOFFMAN, Erving. Estigma: notas sobre a manipulaçăo da identidade deteriorada. Rio de Janeiro: Jorge Zahar, 1982.

GOMES, Marcela A. Os impactos subjetivos dos fluxos migratórios: os haitianos em Florianópolis (SC). Disponível em: http://www.scielo.br/pdf/psoc/v29/1807-0310-psoc-29-e162484.pdf. Acesso em 12 abr. 2017.

GORCZEVSKI, Clóvis. Direitos Humanos Educaçăo e Cidadania. Direitos sociais e políticas públicas: desafios contemporâneos. Santa Cruz do Sul: EDUNISC, 2005.

GRIGOLI, Romulo. Cadeiras ocupadas por haitianos. O Paraná. 19 fev. 2018. Disponível em: https://www.oparana.com.br/noticia/cadeiras-ocupadas-por-haitianos. Acesso em: 01 jan. 2018.

GRONDIN, Marcelo. Haiti: Cultura, poder e desenvolvimento. Săo Paulo: Brasiliense, 1985.

HANDERSON, Joseph. Dólar alto, crise econômica e xenofobia afetam diáspora haitiana no Brasil, afirma pesquisador. Migra Mundo. 22 fev. 2016. Disponível em: http:// migramundo.com/dolar-alto-crise-economica-e-xenofobia-afetam-diaspora-haitiana-no-brasil-afirma-pesquisador/. Acesso em: 30 jul. 2018. 
LACERDA, Mariana. Haiti, SP. Revista Superinteressante. Março 2016.

LAÍNY, Laís. Encontro reunirá haitianos de Cascavel. CGN/Notícias UOL, Sāo Paulo, SP, 12 abr. 2014. Disponível em: https://cgn.inf.br/noticia/87714/encontro-reunira-haitianos-de-cascavel. Acesso em: 12 jun. 2017.

LIMA, M. E. O.; VALA, J. As novas formas de expressáo do preconceito e do racismo. Estudos de Psicologia (UFRN), Natal, v. 9, n. 3, p. 401-411, 2004.

MARANDOLA Jr., E. 2008. Insegurança existencial e vulnerabilidade no habitar metropolitano. Belo Horizonte: Caderno de Geografia, v.18, n.29, p. 39-58.

MASSEY, Douglas et al. The social organization of migration. In: Return to Aztlan - the social process of international migration from Western Mexico. Berkeley: University of California Press, p. 139-171, 199

MATTOS, Alice Lopes; SARTURI, Cristina Arruda; BORGES, Leonardo Antunes. Políticas Públicas de Acolhida a Imigrantes: Discussōes e Experiências. In: REDIN, Giuliana; MINCHOLA, Luís Augusto Bittencourt (Coord.). Imigrantes no Brasil: proteçăo dos direitos humanos e perspectivas político-jurídicas. Curitiba: Juruá, 2015.

MELTON, J. Gordon; BAUMANN, Martin. Religions of the World: A Comprehensive Encyclopedia of Beliefs and Practices. Santa Barbara, CL: ABC-CLIO $2^{\text {a }}$ ed. 2010.

MEZZADRA, Sandro. Derecho de fuga: migraciones, ciudadanía y globalización. Madrid: Traficantes de Sueños, 2005.

MONTEIRO, Luana. Agente penitenciário ameaçou haitianos. Central Gazeta de Notícias. Cascavel/PR. 28 fev. 2014. Disponível em: https://cgn.inf.br/noticia/82979/ agente-penitenciario-ameacou-haitianos. Acesso em: 22 jan. 2018.

MORAES, Wellington de. Entre fronteiras e descasos: Uma análise aceca dos entraves normativos à efetivaçăo dos direito fundamentais ao imigrante na Nova Lei de Migraçăo. 56f. Monografia (Graduaçâo em Direito). Universidade Federal de Santa Maria, Santa Maria, RS, 2017.

PARISE, Paolo. A missāo paz e a acolhida a imigrantes haitianos e haitianas em Săo Paulo. In: BAENINGER, Rosana; PERES, Roberta et al. Imigraçăo Haitiana no Brasil. Jundiaí: Paco Editorial, 2016.

PORTES, Alejandro e József BÖRÖCZ “Contemporary immigration: theoretical perspectives on its determinants and modes of incorporation", International Migration Review, Vol. 28, N 3, pp. 606-630, 1989.

REDIN, Giuliana. Direito de imigrar: direitos humanos e espaço público. Florianópolis: Conceito Editorial, 2013.

RIBEIRO, Ailton A. da Silva. Religiosidade e identidade (s) na diáspora: por uma etnografia entre migrantes haitianos em Porto Velho. Porto Velho: UNIR, 2016. 
RODRIGUES, Luiz Carlos Balga. Francês, crioulo e vodu: a relaçăo entre língua e religiăo no Haiti. Tese (Doutorado em Estudos Lingüísticos Neolatinos - Língua Francesa). 268 f. Rio de Janeiro: UFRJ, 2008.

SAMORA, Daniele Teresa. Um recorte do discurso midiático sobre o processo de imigraçăo Haitiana na Amazônia: uma análise das regularidades discursivas. Dissertaçáo de Mestrado do programa de Pós-Graduaçấo em Letras (PPGL), Fundaçăo Universidade Federal de Rondônia-UNIR, 110 f. Porto Velho, 2015.

SANTOS, Gislene A. Universidade formaçăo cidadania. Săo Paulo: Cortez, 2001.

SASSEN, S.. Inmigrantes y ciudadanos: de las migraciones masivas a la Europa fortaleza. Madrid: Siglo XXI, 2013.

SCHMIDT, Alice Krämer Iorra; VOLKMER, Márcia Solange. 0 acesso à educaçăo aos imigrantes haitianos em uma escola pública em Arroio do Meio. Rio Grande do Sul: UNISC, 2016

SILVA, Sidney A. Imigraçăo e redes de acolhimento: o caso dos haitianos no Brasil. R. bras. Est. Pop., Belo Horizonte, v.34, n.1, p.99-117, jan./abr. 2017.

SOUCHAUD, Sylvain; Rosana BAENINGER. Vínculos entre a Migraçăo Internacional e a Migraçăo Interna: o caso dos bolivianos no Brasil. Brasília: CEPAL, 2007.

SOUZA, Andréia B. de; STEIN, Leila de Menezes. A presença do trabalhador imigrante na cidade de Sáo Paulo: o caso dos haitianos e a proteçăo do visto humanitário. Araraquara: UNESP FCL, 2017.

TILLY, Charles - Transplanted Networks, in YANS-Mc LAUGHLIN (ed.), Virginia, Immigration Reconsidered, NY, Oxford, Oxford University Press, pg.79-95, 1990.

WRONSKI, Fábio. Vídeo mostra haitianos sendo mal atendidos. Central Gazeta de Notícias, Cascavel-PR. 9 jan. 2015. Disponível em: https://cgn.inf.br/noticia/119208/ video-mostra-haitianos-sendo-mal-atendidos. Acesso em: 8 jun. 2018. 